\title{
Chronic guanethidine treatment of female rats including effects on the fetus
}

\author{
Barbara K. Evans and G. Burnstock* \\ Department of Zoology, University of Melbourne, Parkville, Victoria, 3052, Australia
}

\begin{abstract}
Summary. Adult virgin female rats were injected daily with low doses ( 5 or $10 \mathrm{mg} / \mathrm{kg}$ ) or a high dose $(30 \mathrm{mg} / \mathrm{kg})$ of guanethidine for 12 or 8 weeks respectively. 'Short' and 'long' noradrenergic neurones were unaffected by low doses. This contrasts markedly to earlier findings in male rats in which long-term damage of 'short' noradrenergic neurones occurred, and indicates a basic difference between 'short' noradrenergic neurones in male and female rats. Widespread degeneration of both types of neurones followed treatment with high doses and little reinnervation was observed 8 weeks after cessation of treatment. Fertility, pregnancy and litter size were apparently unaffected. Some teratogenic effects were observed in the offspring of female rats treated with guanethidine (10 or $25 \mathrm{mg} / \mathrm{kg} /$ day) before and throughout pregnancy. However, these effects had largely disappeared by the time the offspring were 10 weeks old. Since noradrenergic neurones of newborn rats are particularly sensitive to damage by guanethidine it would appear that either very little guanethidine crosses the placental barrier or that noradrenergic neurones are not susceptible during prenatal development to the cytotoxic effects of guanethidine.
\end{abstract}

\section{Introduction}

Particular interest has been shown in 'short' noradrenergic neurones (Owman \& Sjöstrand, 1965; Sjöstrand, 1965) since they apparently share a number of properties, apart from the length of their axon, which differ considerably from those of ordinary 'long' noradrenergic neurones (see Owman, Sjöberg \& Sjöstrand, 1974). For example, they are more resistant to damage by 6hydroxydopamine (Malmfors \& Sachs, 1968), depletion of noradrenaline stores after reserpine (Sjöstrand \& Swedin, 1968) or $\alpha$-methyl-p-tyrosine (Swedin, 1970) and inhibition of development by anti-nerve growth factor (Hamberger, Levi-Montalcini, Norberg \& Sjöqvist, 1965). On the basis of such results it has been suggested that 'short' noradrenergic neurones constitute a distinct neuronal type. However, most of these studies were carried out using male animals and the 'short' noradrenergic neurones which innervate the male, and part of the female internal genitalia have been shown to differ. Whereas oestrogen and progesterone markedly influence the noradrenaline content of female 'short' noradrenergic neurones (Sjöberg, 1968a, b; Falck, Owman, Rosengren \& Sjöberg, 1969a, b), they have no effect on the noradrenaline content of male 'short' noradrenergic neurones (Owman, Sjöberg, Sjöstrand \& Swedin, 1970).

In male rats and mice the 'short' noradrenergic innervation has been shown to be considerably more sensitive to damage by chronic guanethidine treatment than 'long' noradrenergic neurones (Gannon, Iwayama, Burnstock, Gerkens \& Mashford, 1971; Evans, Gannon, Heath \& Burnstock, 1972; Evans, Iwayama \& Burnstock, 1973; Evans, Heath \& Burnstock, 1979a). The purpose of this study was to investigate the effects of chronic treatment

* Present address: Department of Anatomy and Embryology, University College London, Gower Street, London WC1E 6BT, England. 
with low and high doses of guanethidine, a drug used widely in the treatment of hypertension, on the peripheral noradrenergic neurones of the female rat and particularly to see whether the 'short' noradrenergic neurones are affected earlier or with lower doses. The possibility of damage to fetal noradrenergic neurones as a result of maternally administered guanethidine was also investigated.

\section{Materials and Methods}

Thirty-five (35) adult virgin female rats were injected with guanethidine sulphate (Ismelin: CIBA) at low doses $(5$ or $10 \mathrm{mg} / \mathrm{kg} /$ day $)$ for 12 weeks or a high dose $(30 \mathrm{mg} / \mathrm{kg} / \mathrm{body}$ weight/day) for 8 weeks. The rats were killed by bleeding under light ether anaesthesia at selected intervals during treatment and up to 8 weeks following cessation of treatment. A second group of age-matched untreated female rats served as controls and in all cases control tissue was processed together with the guanethidine-treated tissue. The formaldehyde-induced fluorescence method for the histochemical demonstration of tissue monoamines (Falck \& Owman, 1965), as described in detail elsewhere (Evans et al., 1973), was carried out on the following tissues: right atrium, superior cervical ganglion, iris, coeliac ganglion, ovary, oviduct, uterus, vagina, paracervical ganglion, urethra and ureter. Using light-field illumination it is possible to identify the presence of intact non-fluorescent nerve cell bodies in sympathetic ganglia. The absence of such cells and the continued lack of fluorescence many weeks after cessation of treatment were taken to indicate that degeneration of the noradrenergic neurones had taken place. The validity of this belief has been shown in other studies (Burnstock et al., 1971; Heath et al., 1972; Evans et al., 1979b) using light and electron microscopy.

Another group of 9 virgin female rats were injected with 25,10 or $1 \mathrm{mg}$ guanethidine $/ \mathrm{kg} / \mathrm{day}$ for 2 weeks before mating with normal males. The injections were continued without interruption until the end of pregnancy. The male offspring were killed 1,2 and 10 weeks after birth and tissue from the right atrium, superior cervical ganglion, ileum, vas deferens, epididymis and pelvic plexus was prepared for fluorescence histochemistry. Male offspring were examined since the 'short' noradrenergic neurones supplying the male reproductive tract have been shown to be particularly sensitive to low doses of guanethidine (Gannon et al., 1971; Evans et al., 1972, 1973). One vas deferens from the 10-week-old males was reserved for organ bath experiments where the response to stimulation of intramural nerves and sensitivity to noradrenaline were determined. The conditions and experimental procedure were as described elsewhere (Evans $e t$ al., 1973). After weaning, the mothers were killed and selected tissues processed for fluorescence histochemistry.

\section{Results}

\section{Low doses}

Treatment with low doses ( 5 or $10 \mathrm{mg} / \mathrm{kg} /$ day) of guanethidine caused no change in the fluorescent appearance of the noradrenergic innervation to the right atrium, ureter, iris or of the noradrenergic cell bodies in the superior cervical or coeliac ganglia either during or following treatment.

The noradrenergic nerves supplying the female reproductive tract were also unaffected by low doses of guanethidine. Fluorescent nerve fibres were still clearly visible in the ovary (Pl. 1, Fig. 2), oviduct (Pl. 1, Fig 6), uterus (Pl. 2, Fig. 10) and vagina (Pl. 2, Fig. 14); the pattern and density of this innervation were comparable to that of control tissue (Pl. 1, Figs 1 and 5; Pl. 2, Figs 9 and 13). The general appearance of the paracervical ganglion (Pl. 3, Fig. 21) and the noradrenergic innervation of the urethra was also normal. 


\section{High dose}

The effect of a high dose $(30 \mathrm{mg} / \mathrm{kg} /$ day) of guanethidine on the fluorescence of the noradrenergic innervation of the atrium, iris and on the cells of the superior cervical and coeliac (Pl. 3, Figs 17, 18 and 19) ganglia supported the results of an earlier study (Burnstock, Evans, Gannon, Heath \& James, 1971) in which similar treatment produced a widespread sympathectomy involving the degeneration of over $95 \%$ of peripheral noradrenergic neurones in both male and female rats. The reinnervation of these tissues after cessation of treatment was the same as seen in male rats and is described in detail elsewhere (Evans et al., 1979b).

The normal paracervical ganglion is a diffuse ganglion in which only a small proportion (between 20 and $30 \%$ ) of the nerve cell bodies show weak to moderate fluorescence (Pl. 3, Fig. 20). The remainder are non-fluorescent presumably cholinergic cells (see also Adham \& Schenk, 1969; Kanerva, 1972a, b). A large number of small intensely fluorescent cells in groups of various sizes are scattered throughout the ganglion. After 1 week of treatment with the high dose of guanethidine there was a decrease in the number of fluorescent ganglion cells and after 4 weeks only occasional fluorescent cell bodies were seen. Some perivascular fibres were still present. After treatment for 8 weeks no fluorescent nerve cell bodies or fibres were seen in the ganglion (Pl. 3, Fig. 21). Non-fluorescent ganglion cells were still evident and a few of these appeared vacuolated. There was very little increase in autofluorescent material in the ganglion. The appearance of the ganglion showed little change 8 weeks after cessation of treatment. Only isolated fluorescent ganglion cells were seen and, apart from a partial return of perivascular innervation within the ganglion, very few fluorescent fibres were seen. Non-fluorescent nerve cell bodies and small intensely fluorescent cells in the ganglion appeared normal throughout treatment and recovery.

The fluorescent innervation to the reproductive organs and urethra had decreased greatly after treatment for 1 week. A few fibres were seen in the isthmus of the oviduct (Pl. 1, Fig. 7) and in the vagina (Pl. 2, Fig. 15) but virtually no fibres were seen in the uterus (Pl. 2, Fig. 11), uterotubal junction or ovary. Occasional perivascular fibres were visible throughout the reproductive tract. No fluorescent fibres were present in these organs after treatment for 4 or 8 weeks (Pl. 1, Fig. 3). The very small noradrenergic reinnervation which took place during the 8 weeks following cessation of treatment consisted almost entirely of occasional fluorescent fibres seen on the blood vessels supplying the ovary, oviduct and vagina (Pl. 1, Figs 4 and 8; Pl. 2, Figs 12 and 16).

\section{Fetal effects}

The fluorescent appearance of the noradrenergic neurones of offspring from mothers treated with $1 \mathrm{mg}$ guanethidine $/ \mathrm{kg} /$ day was not different from that of control offspring at any stage examined.

There was a decrease in the fluoresence intensity of noradrenergic fibres in the epididymal end of the vas deferens of 2-week-old offspring from mothers treated with $10 \mathrm{mg}$ guanethidine/ $\mathrm{kg} /$ day (Pl. 4, Fig. 24, compared with Fig. 23). The fluorescent appearance of other tissues from these offspring, including the superior cervical ganglion, atrium (Pl. 4, Fig. 26) and pelvic plexus, was normal. When the rats were 10 weeks old all tissues appeared normal.

Greater effects were seen in the offspring from mothers treated with $25 \mathrm{mg} / \mathrm{kg} /$ day. At 1 week there was a reduction to about $50 \%$ in the intensity of fluorescence of the epididymal end of the vas deferens. By 2 weeks after birth the intensity was still low in the epididymal vas deferens and was also less than control levels in the middle region (about $50 \%$ of normal) and urethral region (about $80 \%$ of normal) of the vas. The noradrenergic nerves of the atrium also showed a reduction of about 50\% in fluorescence intensity (Pl. 4, Fig. 27). The fluorescence of the superior cervical ganglion and the pelvic plexus was not different from control. As with the lower doses, when these offspring were 10 weeks old their noradrenergic innervation was indistinguishable from control in both density and intesnsity of fluorescence (Pl. 4, Figs 25 and 28). 
The fertility of the offspring of mothers treated with 1,10 or $25 \mathrm{mg}$ guanethidine $/ \mathrm{kg} / \mathrm{day}$ was apparently unaffected since in each litter 10-week-old female offspring were pregnant.

A routine fluorescence histochemical survey was carried out on mothers after weaning of their litters. There was no change in the fluorescence of noradrenergic neurones of mothers treated with 1 or $10 \mathrm{mg}$ gaunethidine $/ \mathrm{kg} /$ day (for approximately 5 weeks), but typical high-dose guanethidine-induced damage was found in the mothers treated with $25 \mathrm{mg} / \mathrm{kg} /$ day.

\section{Organ bath physiology}

Organ bath experiments were carried out on vasa deferentia of 10 -week-old rats from mothers treated with guanethidine at $25 \mathrm{mg} / \mathrm{kg} /$ day. Their responses to stimulation of intramural nerves at all frequencies was slightly increased when compared to those of vasa deferentia from control

\section{PLATE 1}

Fluorescence micrographs showing the effects of guanethidine treatment on the noradrenergic innervation of the ovary (Figs 1-4) and oviduct (Figs 5-8). Calibration bar $=100 \mu \mathrm{m}$ and applies to all figures.

Fig. 1. Ovary from control rat showing largely perivascular noradrenergic innervation.

Fig. 2. Rat treated with low doses of guanethidine $(5 \mathrm{mg} / \mathrm{kg} /$ day for 13 weeks). The noradrenergic innervation of the ovary appears normal.

Fig. 3. No fluorescent fibres remain in the ovary after treatment with high doses of guanethidine $(30 \mathrm{mg} / \mathrm{kg} /$ day for 4 weeks).

Fig. 4. By 8 weeks after cessation of treatment with $30 \mathrm{mg} / \mathrm{kg} /$ day for 4 weeks only a small number of pervisacular noradrenergic fibres can be seen (arrow).

Fig. 5. Oviduct from a control rat. There are a considerable number of noradrenergic fibres innervating the smooth muscle in addition to the perivascular fibres.

Fig. 6. Rat treated with low doses of guanethidine $(10 \mathrm{mg} / \mathrm{kg} /$ day for 13 weeks $)$. The noradrenergic innervation of the oviduct appears normal.

Fig. 7. After 1 week of treatment with a high dose of guanethidine $(30 \mathrm{mg} / \mathrm{kg} / \mathrm{day})$ only a few faint perivascular fibres can be seen (arrow).

Fig. 8. By 8 weeks after cessation of high-dose treatment $(30 \mathrm{mg} / \mathrm{kg} /$ day for 8 weeks $)$ the oviduct is devoid of fluorescent fibres.

\section{PLATE 2}

Fluorescence micrographs showing the effects of guanethidine treatment on the noradrenergic innervation of the uterus (Figs 9-12 and vagina Figs 13-16). Calibration bar $=100 \mu \mathrm{m}$ and applies to all figures.

Fig. 9. Uterus from control rat.

Fig. 10. Uterus from a rat treated with low doses of guanethidine $(10 \mathrm{mg} / \mathrm{kg} / \mathrm{day}$ for 13 weeks). The noradrenergic innervation appears normal.

Fig. 11. High doses of guanethidine $(30 \mathrm{mg} / \mathrm{kg} / \mathrm{day}$ for 1 week) depleted the fluorescence from all but a few perivascular fibres (arrow).

Fig. 12. By 8 weeks after cessation of high dose treatment $(30 \mathrm{mg} / \mathrm{kg} /$ day for 8 weeks $)$ no fluorescent fibres are present in the uterus.

Fig. 13. Vagina from a control rat.

Fig. 14. Low doses of guanethidine $(10 \mathrm{mg} / \mathrm{kg} /$ day for 13 weeks $)$ caused no change in fluorescence in the noradrenergic nerves of the vagina.

Fig. 15. No fluorescent fibres remain in the vagina after treatment with high doses of guanethidine $(30 \mathrm{mg} / \mathrm{kg} /$ day for 1 week).

Fig. 16. By 8 weeks after cessation of high dose treatment $(30 \mathrm{mg} / \mathrm{kg} /$ day for 4 weeks) a small number of faintly fluorescent fibres (arrows) can be seen in the vagina. 

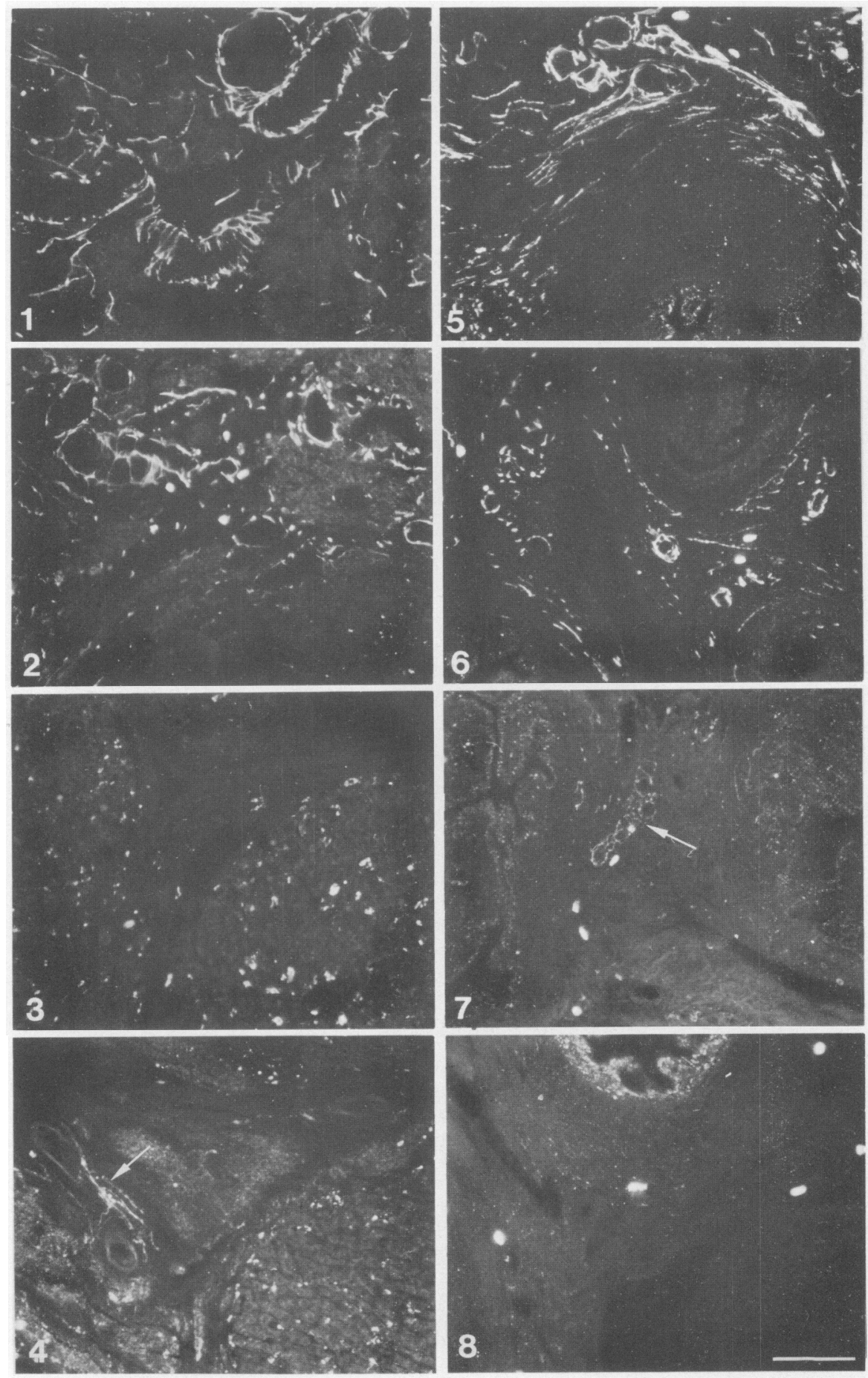


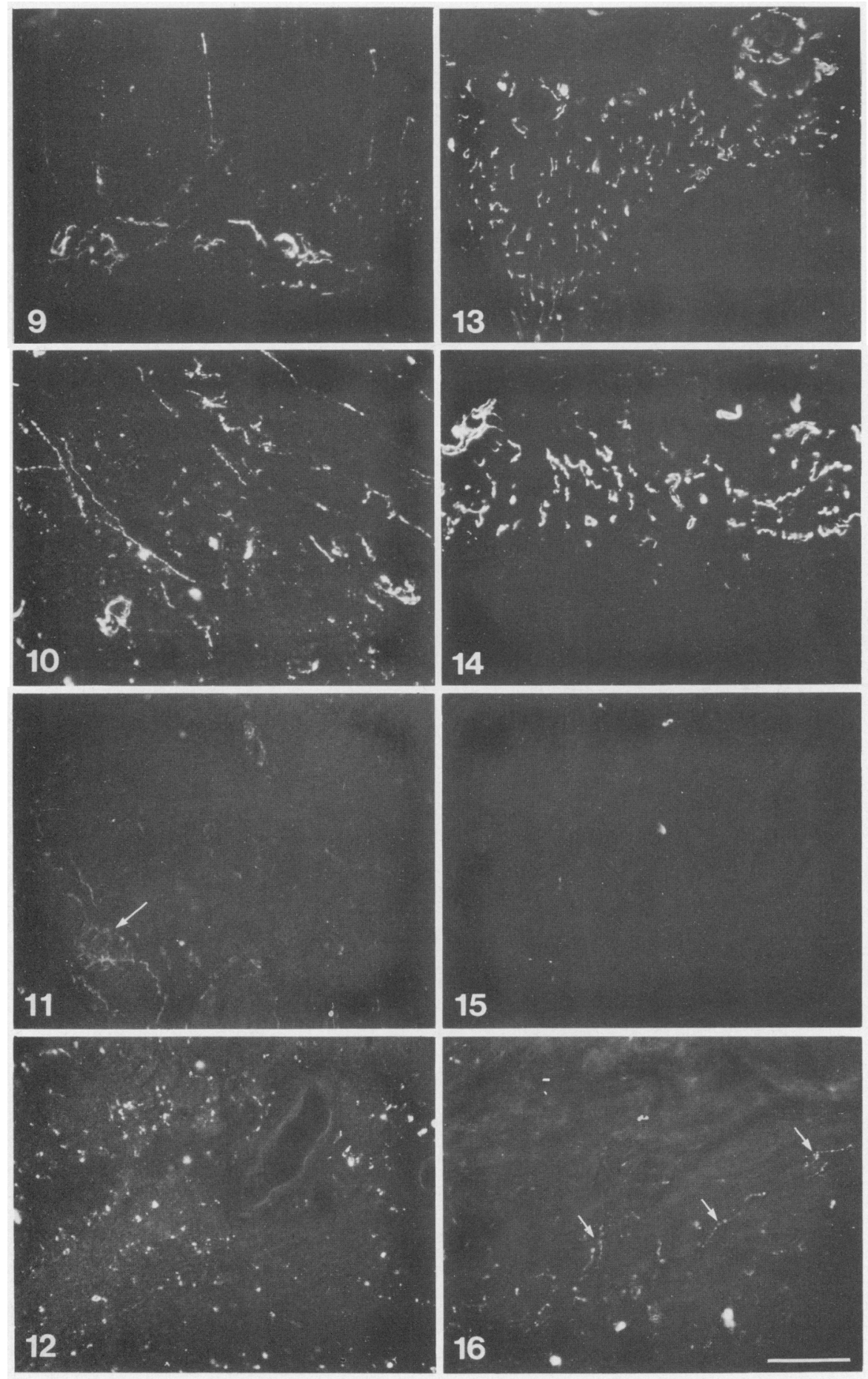




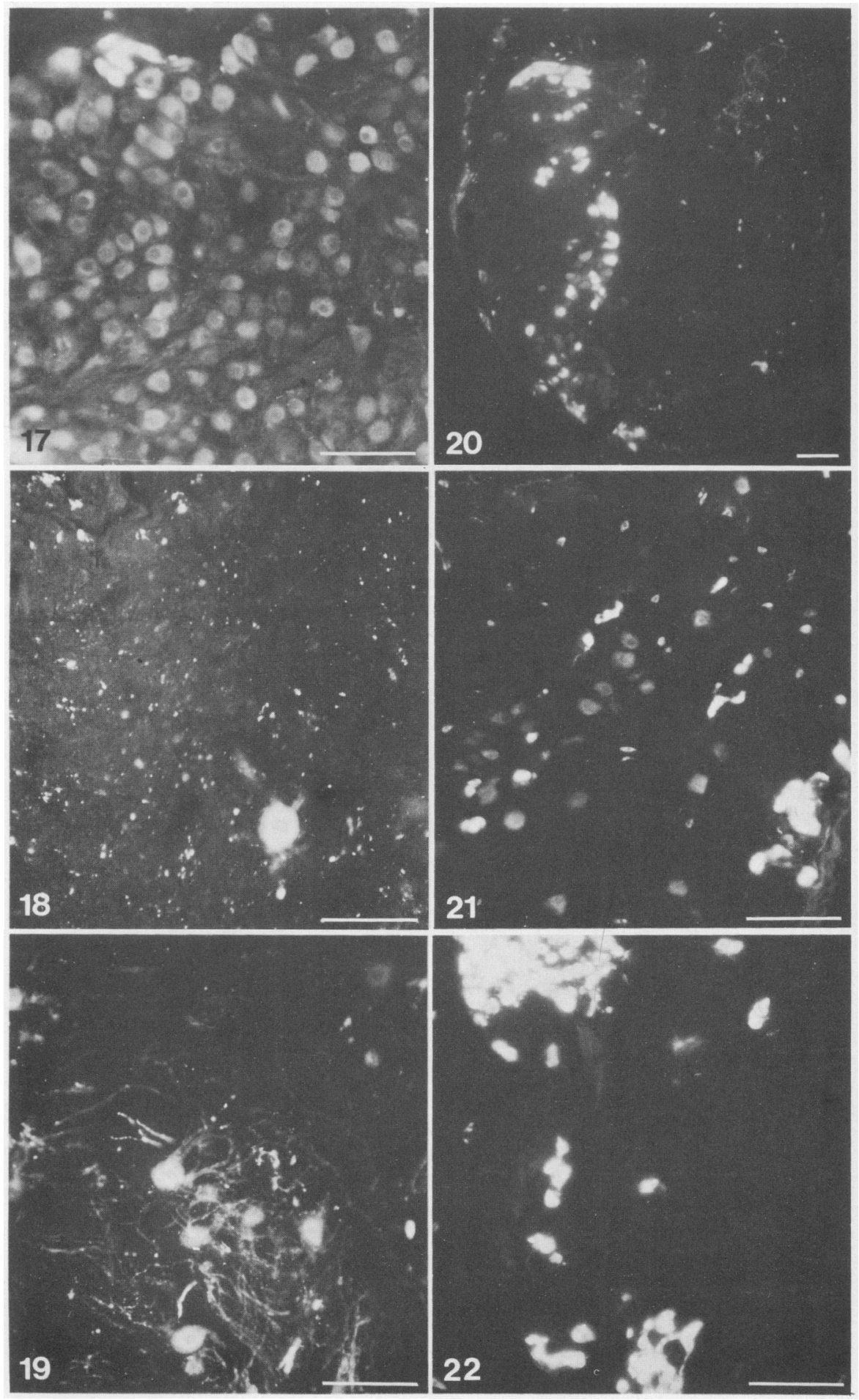




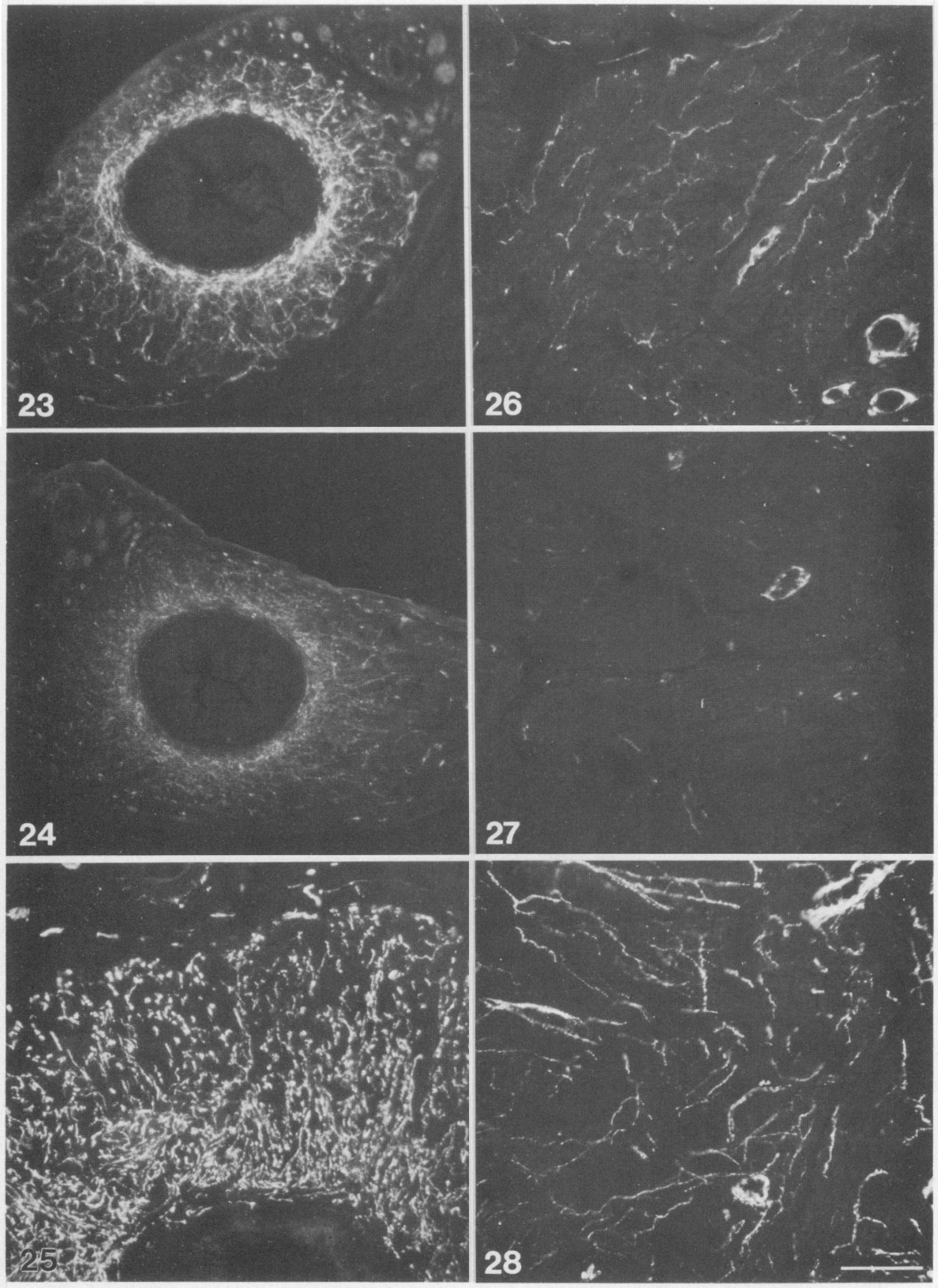


rats of the same age (Text-fig. 1) and their responses to single pulses of $60 \mathrm{~V}$ and $100 \mathrm{~V}$ were $45 \%$ and $30 \%$ respectively greater than control. However, their responses to repetitive stimulation $(10 \mathrm{~Hz}$ for $5 \mathrm{sec}$ every $10 \mathrm{sec}$ ) were more erratic and decreased more quickly than did those of control vasa deferentia (Text-fig. 2). The addition of hyoscine $\left(6 \times 10^{-7} \mathrm{~g} / \mathrm{ml}\right)$ reduced the nerve-mediated response of both control and treated tissue by $7 \%$.

There was no difference in sensitivity of control and treated vasa deferentia to noradrenaline (Text-fig. 3) although the treated vasa deferentia did show a $30 \%$ increase in maximum response to noradrenaline.

\section{Discussion}

According to the classical view of the mammalian autonomic nervous system, the sympathetic system consists of pre-ganglionic fibres arising from the thoracico-lumbar region of the spinal cord which synapse in pre- or paravertebral ganglia with post-ganglionic neurones. The sympathetic innervation of the internal genitalia is an exception to this pattern.

\section{PLATE 3}

Fluorescence micrographs showing the effects of guanethidine-treatment on the noradrenergic innervation of the coeliac (Figs 17-19) and paracervical (Figs 20-22) ganglia. Calibration bars $=100 \mu \mathrm{m}$.

Fig. 17. Coeliac ganglion from female rat treated with high doses of guanethidine $(30 \mathrm{mg} / \mathrm{kg} /$ day for 1 week) is comparable to control.

Fig. 18. Coeliac ganglion from female rat killed after eight weeks of high dose treatment (30 $\mathrm{mg} / \mathrm{kg} /$ day). Only one relatively large fluorescent ganglion cell is visible in the entire field.

Fig. 19. By 8 weeks after cessation of high dose treatment $(30 \mathrm{mg} / \mathrm{kg} / \mathrm{day}$ for 8 weeks) the coeliac ganglion contains a small number of brightly fluorescent ganglion cells which give rise to a considerable number of fluorescent processes.

Fig. 20. Paracervical ganglion from a control rat. Numerous small intensely fluorescent cells and a small number of fluorescent ganglion cells can be seen. The remainder of the ganglion contains non-fluorescent ganglion cells.

Fig. 21. Paracervical ganglion from a rat treated with low doses of guanethidine $(5 \mathrm{mg} / \mathrm{kg} /$ day for 13 weeks). A number of fluorescent ganglion cells can be seen.

Fig. 22. After high doses of guanethidine $(30 \mathrm{mg} / \mathrm{kg} /$ day for 8 weeks) no fluorescent ganglion cells can be seen in the paracervical ganglion. Numerous small intensely fluorescent cells remain.

\section{PLATE 4}

Fluorescence micrographs of vas deferens (Figs 23-25) and atrium (Figs 26-28) taken from the offspring of control female rats and female rats treated with low $(10 \mathrm{mg} / \mathrm{kg} /$ day $)$ and high $(25$ $\mathrm{mg} / \mathrm{kg} /$ day) doses of guanethidine before and throughout pregnancy. Calibration $b a r=100 \mu \mathrm{m}$ and applies to all figures.

Fig. 23. Vas deferens from 2-week-old offspring of control female showing normal noradrenergic innervation.

Fig. 24. Vas deferens from 2-week-old offspring from female treated with low doses of guanethidine. The intensity of fluorescence of the noradrenergic innervation is considerably reduced.

Fig. 25. A 10-week-old offspring of female treated with high doses of guanethidine. The innervation of the vas deferens is normal.

Fig. 26. Apparently normal atrium from 2-week-old offspring from female treated with low doses of guanethidine.

Fig. 27. A 2-week-old offspring of female treated with high doses of guanethidine. The fluorescence of the noradrenergic innervation of the atrium is greatly reduced.

Fig. 28. A 10-week-old offspring of female treated with high doses of guanethidine. The atrium shows a normal innervation of brightly fluorescent fibres. 


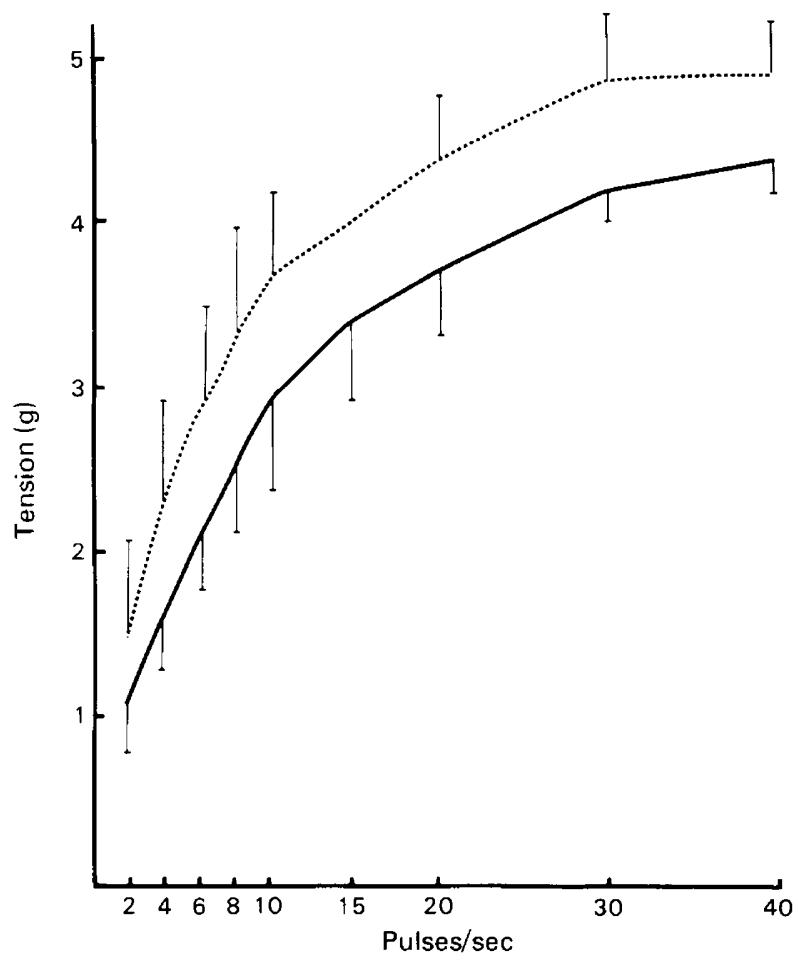

Text-fig. 1. Frequency-response curve for vasa deferentia from the 10 -week-old offspring of control rats ( $\longrightarrow$ ) and rats treated with high doses of guanethidine $(25 \mathrm{mg} / \mathrm{kg} / \mathrm{day})(\cdots)$ before and throughout pregnancy. Vertical bars represent s.e.m. for 4 observations.

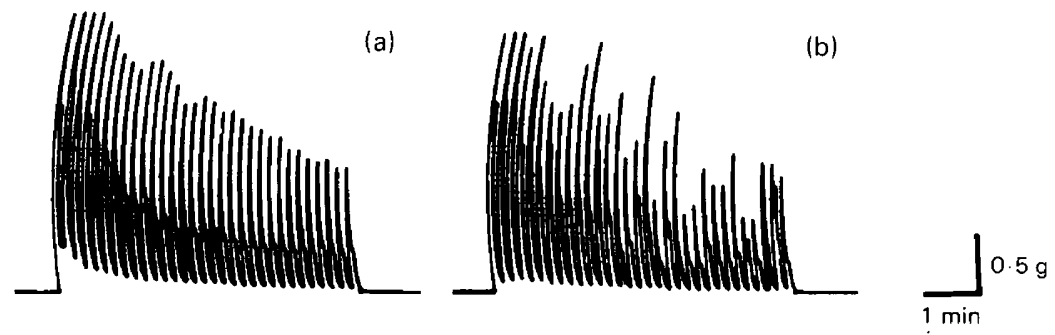

Text-fig. 2. Responses of isolated rat vasa deferentia to electrical stimulation of intramural nerves $(10 \mathrm{~Hz}, 0.2 \mathrm{msec}$ duration for $5 \mathrm{sec}$ every $10 \mathrm{sec})$. The vasa deferentia were taken from 10-week-old offspring of (a) a control rat and (b) a rat treated with high doses of guanethidine $(25 \mathrm{mg} / \mathrm{kg} /$ day) before and throughout pregnancy.

As early as 1895 Langley \& Anderson (1895a, b, 1896) suggested that at least part of the sympathetic post-ganglionic innervation of the male and female internal genitalia may arise in terminal ganglia. It is now well established (see Sjöstrand, 1965; Owman \& Sjöstrand, 1965) that the noradrenergic innervation of the male internal genital organs arises in the peripherally located pelvic plexus (hypogastric ganglion). These neurones were described as 'short' noradrenergic neurones to reflect the shorter length of their post-ganglionic axons.

Studies investigating the origin of the noradrenergic innervation of female internal genitalia in a number of mammalian species including the rat, rabbit, cat and guinea-pig (Brundin, 1965; Norberg \& Fredricsson, 1966; Owman, Rosengren \& Sjöberg, 1966; Rosengren \& Sjöberg, 1967; Sjöberg, 1967; Marshall, 1970; Kanerva, 1972a, b; Kulkarni, Wakade \& Kirpekar, 1976) 


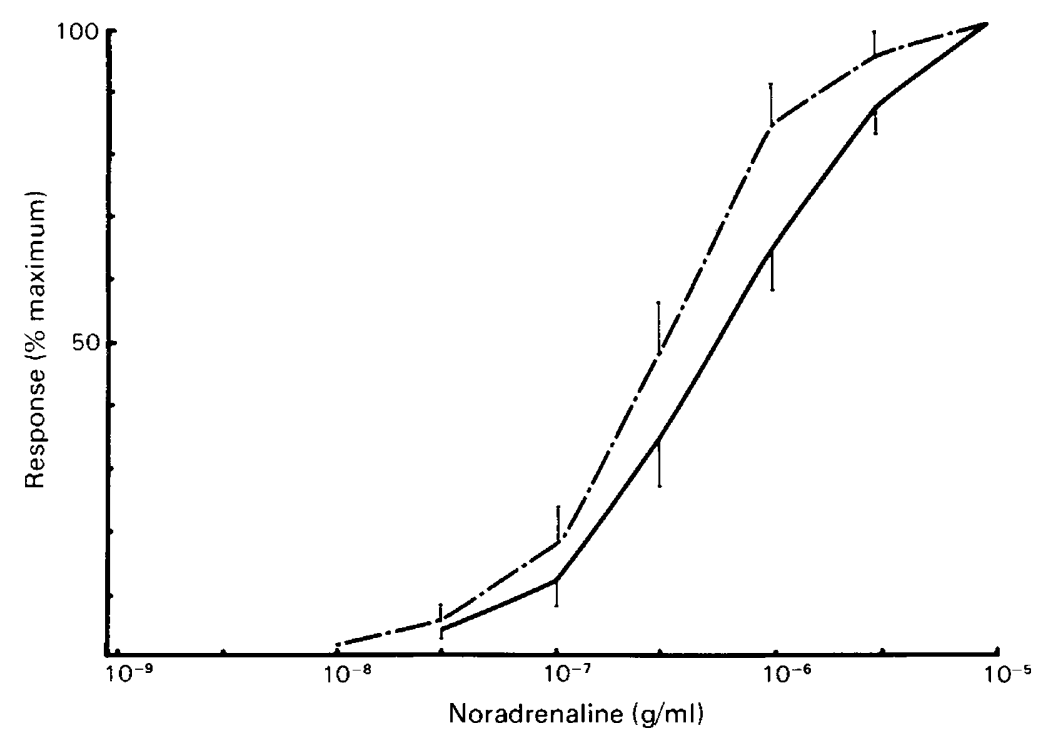

Text-fig. 3. Mean log concentration-response curves for noradrenaline of vasa deferentia from the 10-week-old offspring of untreated female rats $(-)$ and of female rats treated with guanethidine $(25 \mathrm{mg} / \mathrm{kg} / \mathrm{day})(-\cdot-\cdot)$ before and throughout pregnancy. Vertical bars represent s.e.m. for 4 observations.

indicate a considerable species variation in the relative contributions of 'short' noradrenergic neurones located in the paracervical (Frankenhäuser) ganglion and the 'long' noradrenergic neurones of pre- and paravertebral ganglia (see also Sjöberg, 1967). In the rat the innervation pattern appears to be as follows. The ovary is sparsely innervated by 'long' noradrenergic neurones. The oviduct, particularly in the isthmus, has a relatively dense noradrenergic terminal network which arises in roughly equal proportions from both 'long' and 'short' noradrenergic neurones. The sparse noradrenergic innervation of the uterus and relatively dense innervation of the vagina arise largely from 'short' noradrenergic neurones. 'Short' noradrenergic neurones are also believed to innervate the trigonium region of the urinary bladder (Hamberger \& Norberg, 1965a, b) and the urethra (Owman, Owman \& Sjöberg, 1971). 'Long' noradrenergic neurones innervate the blood vessels to these organs.

Whereas male 'short' noradrenergic neurones are selectively and permanently damaged by chronic treatment with low doses of guanethidine (Evans et al., 1972, 1973), female 'short' noradrenergic neurones show no such damage. This striking difference indicates a major difference between male and female 'short' noradrenergic neurones. It is clearly incorrect to consider that male and female 'short' noradrenergic neurones have comparable properties without experimental verification. As mentioned earlier female, but not male, 'short' noradrenergic neurones are affected by oestrogen and progesterone. Also, it is not possible to produce a complete noradrenergic denervation of male internal genitalia with 6-hydroxydopamine, even when it is injected into newborn animals (Jaim-Etcheverry \& Zieher, 1971). However, noradrenergic denervation of female internal genitalia can be achieved by injection of 6-hydroxydopamine into adult female rabbits (Hervonen \& Kanerva, 1974).

Considering male rats only, 'short' and 'long' noradrenergic neurones still do not easily fall into two categories. The 'short' noradrenergic innervation of the trigone of the bladder is not damaged to the same extent as that of the vas deferens and other internal genitalia and there are considerable variations in the effects of intermediate doses of guanethidine $(15 \mathrm{mg} / \mathrm{kg} / \mathrm{day})$ on various tissues innervated by 'long' noradrenergic neurones (Evans, 1979). The effects of 6hydroxydopamine on the 'long' noradrenergic fibres of various systems also vary greatly. 
Gillespie \& McGrath (1972, 1974) found that the 'long' noradrenergic innervation of the anococcygeus muscle and the 'short' noradrenergic innervation of the vas deferens were equally resistant to depletion by reserpine but that the 'long' noradrenergic innervation of the heart was depleted to a much greater extent.

Although it is, at times, convenient to use abbreviations such as 'short' and 'long' to refer to neurone groups it is important to realize that these are generally artificial categories superimposed on natural biological diversity. Even as an anatomical description of the length of the post-ganglionic axon the terms 'long' and 'short' are not precise. The 'short' axons which pass from the pelvic plexus along the length of the vas deferens to innervate the cauda epididymidis would be considerably longer than many 'long' axons which innervate organs and blood vessels in the vicinity of the pre- and paravertebral sympathetic ganglia.

Decentralisation of 'long' noradrenergic neurones increases their susceptibility to damage by guanethidine and it has been suggested that the selective damage of 'short' noradrenergic neurones in male rats by low doses of guanethidine is related to the low levels of physiological activity in these nerves (Evans, 1979). Since guanethidine is released on nerve stimulation as a "false transmitter" (Boullin, Costa \& Brodie, 1966) the tonic activity of many 'long' noradrenergic neurones may sufficiently reduce neuronal levels of guanethidine so as to prevent damage by low doses of the drug. As to the 'short' noradrenergic neurones in females, their physiological role is not well understood (Brundin, 1965; Marshall, 1970); however, their normal physiological activity may be sufficient to reduce intraneuronal levels of guanethidine and prevent neuronal damage. Furthermore, the noradrenergic innervation of the vagina and uterus, as revealed by fluorescence histochemistry, is considerably more dense and prominent during oestrus than during dioestrus and this has been attributed to a cyclical depletion and repletion of noradrenaline during the 4-day oestrous cycle of the rat (Adham \& Schenk, 1969). Since guanethidine acts as a false transmitter these cyclical changes in transmitter content are likely to be paralleled by cyclical changes in guanethidine content which would lessen the overall accumulation of guanethidine during chronic treatment.

Alternatively the difference in guanethidine sensitivity of male and female 'short' noradrenergic neurones may be due to other metabolic differences between these two cell groups. Such an explanation has been proposed to explain why noradrenaline levels of female, but not male 'short' noradrenergic neurones are markedly influenced by oestrogen and progesterone (Owman et al., 1970). The lack of effect of guanethidine on the noradrenergic innervation of the vagina, uterus and oviduct might be interpreted to suggest that, in the rat, none of these organs is innervated by 'short' noradrenergic neurones. However, the cell bodies of the 'short' noradrenergic neurones were examined and these also were clearly undamaged by low doses of guanethidine.

No information is available in the literature regarding the occurrence or extent of placental transfer of guanethidine. If guanethidine is able to cross the placental barrier, then chronic treatment of pregnant rats may result in damage to the developing adrenergic nervous system of offspring. The immature sympathetic neurones of newborn animals are particularly vulnerable to a number of adrenolytic drugs, including guanethidine (Angeletti \& Levi-Montalcini, 1970, 1972; Eränkö \& Eränkö, 1971 a, b).

Typical extensive degeneration of the maternal adrenergic nervous system occurred after treatment of female rats with a high dose of guanethidine before and throughout pregnancy. However, the damage to the adrenergic nervous system of their offspring was much less extensive. While there was a transient $50 \%$ reduction in fluorescence levels there was no indication of degeneration of noradrenergic neurones. Slight differences were also seen in offspring from rats treated with $10 \mathrm{mg}$ guanethidine $/ \mathrm{kg} /$ day. This suggests that either very little of the guanethidine is crossing the placental barrier or that noradrenergic neurones are not susceptible during prenatal development to the degenerating effects of the drug. 
The treatment of female rats before and throughout pregnancy with high doses of guanethidine $(25 \mathrm{mg} / \mathrm{kg} /$ day $)$ resulted in the degeneration of the majority of their peripheral noradrenergic neurones. However, fertility, pregnancy and litter size were apparently unaffected by this treatment. This supports the suggestion that an intact adrenergic innervation is not essential for either ovulation or ovum transport (Johns, Clumecky \& Paton, 1974), particularly in relation to the postulated role of an adrenergic sphincter mechanism in the isthmus of the oviduct (Brundin, 1965, 1969; Pauerstein, Hodgson \& Kramen, 1974). Contrary to the suggestion of Kanerva \& Hervonen (1976), it would appear that an intact adrenergic innervation is also not essential for transport of spermatozoa in the female tract, transport and spacing of embryos before implantation, for maintenance of pregnancy or for parturition.

\section{References}

Adham, N. \& Schenk, E.A. (1969) Autonomic innervation of the rat vagina, cervix and uterus and its cyclic variation. Am. J. Obstet. Gynec. 104, 508-516.

Angeletti, P.V. \& Levi-Montalcini, R. (1970) Sympathetic nerve cell destruction in newborn mammals by 6-hydroxydopamine. Proc, natn. Acad. Sci. U.S.A 65, $114-121$.

Angeletti, P.V. \& Levi-Montalcini, R. (1972) Growth inhibition of sympathetic cells by some adrenergic blocking agents. Proc. natn. Acad. Sci. U.S.A. 69, 86-88.

Boullin, D.J., Costa, E. \& Brodie, B.B. (1966) Discharge of tritium-labelled guanethidine by sympathetic nerve stimulation as evidence that guanethidine is a false transmitter. Life Sci. 5, 803-808.

Brundin, J. (1965) Distribution and function of adrenergic nerves in the rabbit fallopian tube. Acta physiol. scand. 66, Suppl. 259, 1-57.

Brundin, J. (1969) Pharmacology of the oviduct. In The Mammalian Oviduct, pp. 251-269. Eds E. S. E. Hafez \& R. J. Blandau. University of Chicago Press, Chicago.

Burnstock, G., Evans, B., Gannon, B.J., Heath, J.W. \& James, V. (1971) A new method of destroying adrenergic nerves in adult animals using guanethidine. $\mathrm{Br}$. J. Pharmac. 43, 295-301.

Eränkö, L. \& Eränkö, O. (1971a) Effects of guanethidine on nerve cells and small intensely fluorescent cells in sympathetic ganglia of newborn and adult rats. Acta pharmac. toxicol. 30, 403-416.

Eränkö, O. \& Eränkö, L. (1971b) Histochemical evidence of chemical sympathectomy by guanethidine in newborn rats. Histochem. J. 3, 451-456.

Evans, B.K. (1979) Influence of neuronal activity levels on the cytotoxic effects of guanethidine. J. Pharmac. exp. Ther. (in press).

Evans, B., Gannon, B.J., Heath, J.W. \& Burnstock, G. (1972) Long-lasting damage to the internal male genital organs and their adrenergic innervation in rats following chronic treatment with the antihypertensive drug guanethidine. Fert. Steril. 23, 657-667.

Evans, B., Iwayama, T. \& Burnstock, G. (1973) Longlasting supersensitivity of the rat vas deferens to norepinephrine after chronic guanethidine administration. J. Pharmac. exp. Ther. 185, 60-69.

Evans, B.K., Heath, J.W. \& Burnstock, G. (1979a) Effects of chronic guanethidine on the sympathetic nervous system of mouse and toad. Comp. Biochem. Pharmac. (in press).

Evans, B.K., Heath, J.W. \& Burnstock, G. (1979b) Reinnervation following guanethidine-induced sympathectomy of adult rats. J. Neurocytol. (in press).

Falck, B. \& Owman, Ch. (1965) A detailed methodological description of the fluorescence method for the cellular demonstration of biogenic monoamines. Acta Univ. Lund II 7, 1-24.

Falck, B., Owman, Ch., Rosengren, E. \& Sjöberg, N.O. (1969a) Persisting high level of transmitter in uterine short adrenergic neurons following prolonged treatment with 17ß-Oestradiol. Acta endocr., Copenh. 62 , 77-81.

Falck, B., Owman, Ch., Rosengren, E. \& Sjöberg, N.O. (1969b) Reduction by progesterone of the estrogeninduced increase in transmitter level of the short adrenergic neurons innervating the uterus. Endocrinology 84, 958-962.

Gannon, B.J., Iwayama, T., Burnstock, G., Gerkens, J. \& Mashford, M.L. (1971) Prolonged effects of chronic guanethidine treatment on the sympathetic innervation of the genitalia of male rats. Med. $J$. Aust. 2, 207-208.

Gillespie, J.S. \& McGrath, J.C. (1972) The effect of nerve stimulation on the depletion of noradrenaline by reserpine in the heart, vas deferens and anococcygeus muscle of the rat. Br. J. Pharmac. 46, 525$526 \mathrm{P}$.

Gillespie, J.S. \& McGrath, J.C. (1974) The effect of pithing and of nerve stimulation on the depletion of noradrenaline by reserpine in the rat anococcygeus muscle and vas deferens. Br. J. Pharmac. 52, 585590.

Hamberger, B. \& Norberg, K.-A. (1965a) Adrenergic synaptic terminals and nerve cells in bladder ganglia of the cat. Int. J. Neuro-pharmac. 4, 41-45.

Hamberger, B. \& Norberg, K.-A. (1965b) Studies on some systems of adrenergic synaptic terminals in the abdominal ganglia of the cat. Acta physiol. scand. 65, 235-242.

Hamberger, B., Levi-Montalcini, R., Norberg, K.-A. \& Sjöqvist, F. (1965) Monoamines in immunosympathectomized rats. Int. J. Neuro-pharmac. 4, 91-95.

Heath, J.W., Evans, B.K., Gannon, B.J., Burnstock, G. \& James, V.B. (1972) Degeneration of adrenergic neurons following gaunethidine treatment: an ultra- 
structural study. Virchows Arch. Abt. B: Zellpath. II, 182-197.

Hervonen, A. \& Kanerva, L. (1974) Effect of 6-OHDopamine on autonomic nerves of the rabbit myometrium. Acta physiol. scand. 90, 107-112.

Jaim-Etcheverry, G. \& Zieher, L.M. (1971) Permanent depletion of peripheral norepinephrine in rats treated at birth with 6-hydroxydopamine. Eur. J. Pharmac. 13, 272-276.

Johns, A., Clumecky, J. \& Paton, D.M. (1974) Role of adrenergic nerves in ovulation and ovum transport. Lancet ii, 1079.

Kanerva, L. (1972a) Development, histochemistry and connections of the paracervical (Frankenhäuser) ganglion of the rat uterus: a light and electron microscopical study. Acta Inst. anat. Univ. Helsingf. Suppl. 2, 1-31.

Kanerva, L. (1972b) Ultrastructure of sympathetic ganglion cells and granule-containing cells in the paracervical (Frankenhäuser) ganglion of the newborn rat. Z. Zellforsch. mikrosk Anat. 126, 25-40.

Kanerva, L. \& Hervonen, A. (1976) SIF cells, short adrenergic neurons and vacuolated nerve cells of the paracervical (Frankenhäuser) ganglion. In SIF Cells: Structure and Function of the Small Intensely Fluorescent Sympathetic Cells, pp. 19-34. Ed. O. Eränkö. Fogarty Int. Cent. Proc. 30, DHEW Publ. 76-942, Washington.

Kulkami, P.S., Wakade, A.R. \& Kirpekar, S.M. (1976) Sympathetic innervation of guinea-pig uterus and ovary. Am. J. Physiol. 230, 1400-1405.

Langley, J.N. \& Anderson, H.K. (1895a) The innervation of the pelvic and adjoining viscera. Part IV, The internal generative organs. J. Physiol., Lond. 19, $122-130$.

Langley, J.N. \& Anderson, H.K. (1895b) The innervation of the pelvic and adjoining viscera. Part V, Position of the nerve cells on the course of efferent nerve fibres. J. Physiol., Lond. 19, 131-139.

Langley, J.N. \& Anderson, H.K. (1896) The innervation of the pelvic and adjoining viscera. Part VII, Anatomical observations. J. Physiol., Lond. 20, 372-406.

Malmfors, T. \& Sachs, C. (1968) Degeneration of adrenergic nerves produced by 6-hydroxydopamine. Eur. J. Pharmac. 3, 89-92.

Marshall, J.M. (1970) Adrenergic innervation of the female reproductive tract: anatomy, physiology and pharmacology. Ergebn. Anat. EntwGesch. 62, 6-67.

Norberg, K.-A. \& Fredricsson, B. (1966) Cellular distribution of monoamines in the uterine and tubal walls of the rat. Acta physiol. scand. 68, Suppl. $277,149$.
Owman, Ch. \& Sjöstrand, N.-O. (1965) Short adrenergic neurons and catecholamine-containing cells in vas deferens and accessory male genital glands of different mammals. Z. Zellforsch. mikrosk. Anat. 11, 300-320.

Owman, Ch., Rosengren, E. \& Sjöberg, N.-O. (1966) Origin of the adrenergic innervation to the female genital tract of the rabbit. Life Sci. 5, 1389-1396.

Owman, Ch., Sjöberg, N.-O., Sjöstrand, N.O. \& Swedin, G. (1970) Effect of high doses of oestrogen and progesterone on the noradrenaline content of the short adrenergic neurons innervating the male genital tract of the rat. Acta endocr., Copenh. 64, 459-465.

Owman, Ch., Owman, T. \& Sjöberg, N.-O. (1971) Short adrenergic neurons innervating the female urethra of the cat. Experientia 27, 313-315.

Owman, Ch., Sjöberg, N.-O. \& Sjöstrand, N.O. (1974) Short adrenergic neurons-a peripheral neuroendocrine mechanism. In Amine Fluorescence Histochemistry, pp. 47-66. Eds M. Fujiwara \& C. Tanaka. Igaku Shoin Ltd, Tokyo.

Pauerstein, C.J., Hodgson, B.J. \& Kramen, M. (1974) The anatomy and physiology of the fallopian tube. Obstet. Gynecol. Ann. 1974, 137-202.

Rosengren, E. \& Sjöberg, N.-O. (1967) The adrenergic nerve supply to the female reproductive tract of the cat. Am. J. Anat. 121, 271-284.

Sjöberg, N.-O. (1967) The adrenergic transmitter of the female reproductive tract: distribution and functional changes. Acta physiol. scand. Suppl. 305, 1-32.

Sjöberg, N.-O. (1968a) Considerations on the cause of disappearance of the adrenergic transmitter in uterine nerves during pregnancy. Acta physiol. scand. 72, 510-517.

Sjöberg, N.-O. (1968b) Increase in transmitter content of adrenergic nerves in the reproductive tract of female rabbits after oestrogen treatment. Acta endocr., Copenh. 57, 405-413.

Sjöstrand, N.O. (1965) The adrenergic innervation of the vas deferens and the accessory male genital glands. Acta physiol. scand. 65, Suppl. 257, 1-82.

Sjöstrand, N.O. \& Swedin, G. (1968) Effect of reserpine on the noradrenaline content of the vas deferens and the seminal vesicle compared with the submaxillary gland and the heart of the rat. Acta physiol. scand. 72, 370-377.

Swedin, G. (1970) Comparison of the effects of $\alpha$ methyltyrosine on the noradrenaline stores of different peripheral organs of the rat. Life Sci. 9, 12491259. 